\title{
An Experimental Study on the Mechanical and Durability Properties of Concrete: Partial Replacement of Fine Aggregate with Steel Slag, Manufacturing Sand and Bottom Ash
}

\author{
Dr. B. Vidivelli ${ }^{1}$, R. Divya ${ }^{2}$ \\ ${ }^{1}$ Professor, Department of Civil Engineering, Annamalai University, India \\ ${ }^{2} P G$ Student, Department of Civil Engineering, Annamalai University, India
}

\begin{abstract}
As construction industries are increasing at faster rate consumption of naturally available sand is more now-a-days. The fine aggregate which we use for construction is available from natural rivers and streams use of large amount of fine aggregate affects the environment. This present study had been carried out to investigate the possibility of utilizing a broad range of concrete raw materials as partial replacement for fine aggregate in the production of concrete. In this study replacement of fine aggregate with steel slag, $M$-sand and bottom ash with 10\%, 20\%,30\%, 40\% and 50\% for grade of concrete M30are tested for finding fresh and hardened properties of concrete to identify the optimum percentage of three fine aggregate replacement materials in concrete. M30 grade of concrete tested in compressive strength at the age of 28, 56, 90 and 180 days, flexural strength and modulus of elasticity at the age of 28 days curing and also to determine the durability properties of replacement materials concrete. Rapid Chloride Penetration Test, Salt resistance and Sulphate Resistance are to be conducted. Using origin pro software to arrive formulate regression equations for the properties of concrete.
\end{abstract}

Keywords: Steel slag, M-sand, Bottom ash, Compressive strength, Flexural strength, Modulus of elasticity, Rapid chloride penetration test, Salt resistances and Sulphate resistance.

\section{Introduction}

Concrete is the most widely used material for construction since several years. It is the choice of material in construction industry due to its inherent properties of versatility, durability and ease of construction. Large quantities of waste materials and by-product are generated from manufacturing process and industries. As a result, proper disposal of such material becomes one of the major environmental concerns in the world. The aim of the present study is to utilize the industrial by-product waste in concrete effectively. In this project steel slag, manufacturing sand and bottom ash is used in concrete for replacement as fine aggregate. The strength properties in concrete are determined with the various replacement level of the fine aggregate. This project intention on the optimization of replacement of fine aggregate in the concrete mix of $\mathrm{M}_{30}$ grade. The arguments are mostly in regard to protect river beds against the erosion and the importance of having natural sand as a filter for ground water. For these reasons, periodic restrictions are being introduced by governmental authorities against the collection of river sand. Recently many countries have established policies aimed at utilizing the local waste material as much as possible for building construction. The growing shortage and price rise of the natural sand also raise questions that a construction industry shall think about it. Due to short supply of natural sand and the increased activity in construction sector, it has become an imperative to look for viable alternatives to natural sand. With natural sand deposits the world over drying up, there is an acute need for a product that matches the properties of natural sand in concrete. On other hand industrializing, rapid growth of industries in India gave birth to numerous kinds of waste products. The steady increase in demands due to population growth as also resulted in increase in production and as the production rate increase to match the consumption rate the waste produced by the process during production also increases proportionality. But the waste products generated by these industries is causing environmental hazards as their disposal being a major problem, due to this over the period of time waste management has become one of the most complex and challenging problems in India.

\section{Literature Collection}

Iman et al, (2016) carried out an experimental study of partial replacement of fine aggregate with waste material from bottom ash. From the results bottom ash was added in different mix proportion to partially replace natural sand. The specimens were tested to find their mechanical properties. Prithviraj et al, (2016) studied the fine aggregate available from natural river and streams which are used for construction. Steel Slag which was the waste material available from industries producing steel products or working on steel in steel manufacturing industries. This research aimed to study the effect of Steel Slag as partial replacement of fine aggregate with different proportion. It was concluded that the $30 \%$ replacements were desirable replacements for fine 
aggregate. Arun et al, (2015) experimentally studied the mechanical properties of structural concrete with fine aggregate recycled steel slag. The steel slag was added in different mix proportion to partially replace the natural sand. The specimen was tested to find compressive strength, split tensile strength, flexural strength and modulus of elasticity of concrete. The test result indicated the optimum replacement level of fine aggregate with steel slag as $40 \%$. Yajurved et al, (2015) described that the strength of $\mathrm{M}_{20}$ and $\mathrm{M}_{30}$ concrete by replacement of fine aggregate with manufacturing sand. M-sand waste products were used as fine aggregate and the properties of resultant mix were studied and compare with the control mix having normal aggregate. Manufacturing sand was added in different mix proportion to partially replace the natural sand. Naveenth et al, (2015) described that the compressive strength for 7,14 and 28 days for curing for the concrete cubes keeps on increasing with the percentage of manufacturing sand replacement up to $60 \%$, the compressive strength decreases. The overall strength of concrete linearly increases from $0 \%, 20 \%, 40 \%, 60 \%$ and start decreasing above $80 \%$ replacement of natural sand by manufacturing sand. The optimum percentage of replacement of natural sand manufacturing sand is $60 \%$.

\section{Materials}

Currently India has taken a major initiative in developing its infrastructure such as highways, dams, industrial structures and power projects to meet into globalization requirements. Concrete thus plays a big role and large quantities are being utilized, so there is high demand like resources like river sand which has become highly expensive and scare, transportation of river sand from its sources also an increase the cost of producing concrete. There is thus a need for alternative materials from industrial waste to act as sand replacement and thus address the problems in here not in the use of sand as fine aggregate. In such case replacement materials can be economical alternative to natural sand. Steel slag is a by-product obtained from conversion of iron to steel in the steel manufacturing industries. Steel slag is generated as a melt at about $1600^{\circ} \mathrm{C}$ during steel making from hot metal in the amount of $15 \%-20 \%$ per equivalent unit of steel. The function of the steel slag is to the steel of sulphur and to absorb the oxides formed as a result of de-oxidation during steel production. M-Sand is crushed aggregates produced from hard granite stone which is cubically shaped with ground edges, washes and graded with consistency to be used a substitute for natural river sand. It is also referred to as crushed rock sand, stone sand, crusher sand and crushed fine aggregate. M-sand consists of the graded mix of coarse sand, medium sand and fine particles, known as filler grade. The coal is collected from the bottom of furnace is called coal bottom ash. Bottom ash is chiefly included of fused coarser ash particles. Material obtained on $4.75 \mathrm{~mm}$ sieve is termed as coarse aggregate crushed stone and natural gravel are the common materials used as coarse aggregate for concrete. Natural gravels can be quarried from pits where they have been deposited by alluvial or glacial action, and are normally composed of flint, quartz, schist and igneous rocks.

\section{Experimental Programme}

The experimental investigations are planned to study the performance of concrete when added with admixtures partially. Different mix proportions are designed and standardized. The aim of the project is to determine the compressive strength of concrete. The properties of different materials to be used are determined by standard laboratory tests. Finally, the results of the preliminary studies are discussed and summarized. The M30 mix design details are given in the Annexure and referred from the codal provision as per IS 456:2000 and IS 10262:2009. The trial mix proportion are presented Table 1.

Mix proportion was confirmed by trial mixes. Target slump value is $50-75 \mathrm{~mm}$. The achieved slump value is $60 \mathrm{~mm}$. Slump test is conducted on the fresh concrete. The cube moulds of required size $(150 \times 150 \times 150$ $\mathrm{mm}$ ) shall be made in such a manner as to facilitate their separation into two parts. Cube moulds shall be provided with a base plate and they shall be as per IS: 10086-1982. The remixed concrete is filled the mould in three layers and each layer is damped with damping rod. As per IS: 10086-1982, the damping rod shall be $16 \pm 0.5 \mathrm{~mm}$ dia and $600 \pm 2 \mathrm{~mm}$ long with a rounded working end and shall be made of mild steel. The test specimens shall be stored in a place, free from vibration at a temperature of $27^{\circ} \pm 2^{\circ} \mathrm{C}$ for 24 hours $\pm 1 / 2$ hour from the time od addition of water to the dry ingredients. After this period, the specimens shall be marked and removed from the mould and, unless required for test within 24 hours, immediately submerged in clean, fresh water. The conventional and replacement specimens were cast using steel slag, bottom ash and M-sand as replacement materials for fine aggregate. The totally 84 specimens were casted. 93 cubes (150x150x150mm), 12 prisms $(100 \times 100 \times 500 \mathrm{~mm}), 12$ cylinders $(150 \times 300 \mathrm{~mm})$ and 8 cylinders $(100 \times 200 \mathrm{~mm})$. 
An Experimental Study on the Mechanical and Durability Properties of Concrete: Partial ..

Table 1 Mix Proportions of concrete

\begin{tabular}{|l|l|l|l|l|l|l|l|}
\hline $\begin{array}{l}\text { Trial } \\
\text { Mix }\end{array}$ & $\begin{array}{l}\text { Cement } \\
\left(\mathbf{k g} / \mathbf{m}^{\mathbf{3}}\right)\end{array}$ & $\begin{array}{l}\text { w/c } \\
\text { Ratio }\end{array}$ & $\begin{array}{l}\mathbf{F A} \\
\left(\mathbf{k g} / \mathbf{m}^{\mathbf{3}}\right)\end{array}$ & $\begin{array}{l}\mathbf{C A} \\
\left(\mathbf{k g} / \mathbf{m}^{\mathbf{3}}\right)\end{array}$ & $\begin{array}{l}\text { Water } \\
\left(\mathbf{l i t} / \mathbf{m}^{\mathbf{3}}\right)\end{array}$ & $\begin{array}{l}\text { SP } \\
\left(\mathbf{l i t} / \mathbf{m}^{\mathbf{3}}\right)\end{array}$ & $\begin{array}{l}\text { Slump } \\
(\mathbf{m m})\end{array}$ \\
\hline 1 & 426.66 & 0.45 & 657.32 & 1148.79 & 192 & - & 25 \\
\hline 2 & 384 & 0.50 & 652.72 & 1191.055 & 192 & - & 25 \\
\hline 3 & 432 & 0.40 & 609.72 & 1249.68 & $\begin{array}{l}10 \% \text { Water Reduced } \\
172.8\end{array}$ & $\begin{array}{l}1 \% \\
4.32\end{array}$ & Collapse \\
\hline $\mathbf{4}$ & $\mathbf{4 3 2}$ & $\mathbf{0 . 4 0}$ & $\mathbf{6 1 8 . 8 0 3}$ & $\mathbf{1 2 3 2 . 9 3}$ & $\mathbf{1 7 2 . 8}$ & $\begin{array}{l}\mathbf{0 . 3 \%} \\
\mathbf{1 . 2 9 6}\end{array}$ & $\mathbf{6 0}$ \\
\hline
\end{tabular}

The 45 cubes were cast using replacement material in fifteen mix proportions, the cubes were kept under curing condition after they were removed from the mould after 24 hours. To determine the compressive strength of three different replacement materials in various mix proportion, the cubes were tested after 7 days curing. The details of mix design used in experimental program are given Table 2.

Table 2 Replacement \% of Mix design

\begin{tabular}{|c|c|c|c|c|c|}
\hline Trial Mix & $\begin{array}{c}\text { FA } \\
\left(\mathrm{kg} / \mathrm{m}^{3}\right)\end{array}$ & $\begin{array}{l}\text { Steel Slag } \\
\left(\mathrm{kg} / \mathrm{m}^{3}\right)\end{array}$ & $\begin{array}{l}\text { Bottom Ash } \\
\left(\mathrm{kg} / \mathrm{m}^{3}\right)\end{array}$ & $\begin{array}{c}\text { M-Sand } \\
\left(\mathrm{kg} / \mathrm{m}^{3}\right)\end{array}$ & $\begin{array}{c}\text { SP } \\
\left(\mathbf{l i t} / \mathbf{m}^{3}\right)\end{array}$ \\
\hline SS-10\% & 542.845 & 75.958 & - & - & 1.296 \\
\hline SS-20\% & 466.887 & 151.916 & - & - & 1.296 \\
\hline SS-30\% & 390.929 & 227.874 & - & - & 1.3392 \\
\hline SS-40\% & 314.971 & 303.832 & - & - & 1.3600 \\
\hline $\mathrm{SS}-50 \%$ & 239.031 & 379.790 & - & - & 1.3824 \\
\hline BA-10\% & 559.621 & - & 59.182 & - & 1.3392 \\
\hline BA-20\% & 500.439 & - & 118.364 & - & 1.3608 \\
\hline BA-30\% & 441.257 & - & 177.546 & - & 1.3737 \\
\hline BA- $40 \%$ & 382.075 & - & 236.728 & - & 1.3824 \\
\hline BA-50\% & 322.893 & - & 295.910 & - & 1.3910 \\
\hline MS-10\% & 558.223 & - & - & 60.58 & 1.2960 \\
\hline MS-20\% & 497.643 & - & - & 121.16 & 1.2960 \\
\hline MS-30\% & 437.063 & - & - & 181.74 & 1.3392 \\
\hline MS-40\% & 376.483 & - & - & 242.32 & 1.3608 \\
\hline MS-50\% & 315.903 & - & - & 302.90 & 1.3730 \\
\hline
\end{tabular}

\section{Results And Discussion}

To predict the mechanical properties of conventional concrete and replacement materials concrete used tests are compressive strength test, flexural strength test and modulus of elasticity test.

\section{Mechanical Properties}

In the case of cubes, the specimen is placed in the machine in such a manner that the load is applied to opposite sides of the cubes as cast. The axis of the specimen is carefully aligned with the centre of thrust of the spherically seated plate. No packaging is used between the faces of the test specimen and the steel plate of the testing machine. A spherically seated block is brought to bear on the specimen, the movable portion is rotated gently by hand so that uniform seating may be obtained. The load is applied without shock and increased continuously until the resistance of the specimen to the increasing load breaks down and no greater load can be sustained. The maximum load to the specimen is then recorded. After 28 days of curing the prisms were taken out from the curing tank, weighed and tested for modulus of rupture under two-point loading in a flexure testing machine according to IS: 516-1959. The cylinder was placed inside the young's modulus testing apparatus called compressometer, providing equal clearance to top and bottom of the specimen. For each mix three cylinder of size $150 \mathrm{~mm}$ in diameter and $300 \mathrm{~mm}$ in length were cast and cured for 28 days to determine the modulus of elasticity of concrete. Each e-for concrete results is the average of 3 test results. Each cylinder was tested in 200T capacity compression testing machine (CTM). The optimum percentage replacement of steel slag, bottom ash and M-Sand materials in 7 days strength was presented in Table 3, 4 and 5. 
An Experimental Study on the Mechanical and Durability Properties of Concrete: Partial ..

Table 3 Optimum Percentage Replacement of Steel Slag in 7 Days Strength

\begin{tabular}{|c|c|c|c|c|}
\hline Mix & $\begin{array}{c}\text { Weight of Cube } \\
(\mathrm{kg})\end{array}$ & $\begin{array}{c}\text { Load } \\
(\mathbf{k N})\end{array}$ & $\begin{array}{c}\text { Compressive } \\
\text { Strength }\left(\mathbf{N} / \mathbf{m m}^{2}\right)\end{array}$ & $\begin{array}{l}\text { Average Compressive } \\
\text { Strength }\left(\mathrm{N} / \mathrm{mm}^{2}\right)\end{array}$ \\
\hline \multirow{3}{*}{$10 \%$} & 8.753 & 649 & 28.84 & \multirow{3}{*}{28.98} \\
\hline & 8.893 & 650 & 28.88 & \\
\hline & 8.985 & 658 & 29.24 & \\
\hline \multirow{3}{*}{$20 \%$} & 8.798 & 793 & 35.24 & \multirow{3}{*}{34.16} \\
\hline & 8.863 & 752 & 33.42 & \\
\hline & 8.957 & 761 & 33.84 & \\
\hline \multirow{3}{*}{$30 \%$} & 8.700 & 480 & 21.33 & \multirow{3}{*}{24.73} \\
\hline & 8.634 & 542 & 24.08 & \\
\hline & 8.674 & 648 & 28.8 & \\
\hline \multirow{3}{*}{$40 \%$} & 8.812 & 717 & 31.86 & \multirow{3}{*}{30.61} \\
\hline & 8.742 & 692 & 30.75 & \\
\hline & 8.611 & 652 & 29.24 & \\
\hline \multirow{3}{*}{$50 \%$} & 8.802 & 670 & 29.77 & \multirow{3}{*}{30.60} \\
\hline & 8.842 & 694 & 30.84 & \\
\hline & 8.903 & 702 & 31.20 & \\
\hline
\end{tabular}

Table 4 Optimum Percentage Replacement of Bottom Ash in 7 Days Strength

\begin{tabular}{|c|c|c|c|c|}
\hline Mix & $\begin{array}{c}\text { Weight of Cube } \\
(\mathrm{kg})\end{array}$ & $\begin{array}{c}\text { Load } \\
(\mathbf{k N})\end{array}$ & $\begin{array}{c}\text { Compressive } \\
\text { Strength }\left(\mathbf{N} / \mathbf{m m}^{2}\right)\end{array}$ & $\begin{array}{l}\text { Average Compressive } \\
\text { Strength }\left(\mathbf{N} / \mathbf{m m}^{2}\right)\end{array}$ \\
\hline \multirow{3}{*}{$10 \%$} & 8.400 & 415 & 18.44 & \multirow{3}{*}{19.27} \\
\hline & 8.424 & 422 & 18.75 & \\
\hline & 8.460 & 464 & 20.62 & \\
\hline \multirow{3}{*}{$20 \%$} & 8.559 & 561 & 24.93 & \multirow{3}{*}{26.84} \\
\hline & 8.542 & 621 & 27.6 & \\
\hline & 8.561 & 630 & 28.0 & \\
\hline \multirow{3}{*}{$30 \%$} & 8.581 & 678 & 30.13 & \multirow{3}{*}{28.29} \\
\hline & 8.524 & 598 & 26.57 & \\
\hline & 8.553 & 634 & 28.17 & \\
\hline \multirow{3}{*}{$40 \%$} & 8.576 & 727 & 32.31 & \multirow{3}{*}{31.71} \\
\hline & 8.492 & 719 & 31.95 & \\
\hline & 8.384 & 695 & 30.88 & \\
\hline \multirow{3}{*}{$50 \%$} & 8.582 & 754 & 33.51 & \multirow{3}{*}{29.82} \\
\hline & 8.524 & 619 & 27.51 & \\
\hline & 8.577 & 640 & 28.44 & \\
\hline
\end{tabular}

Table 5 Optimum Percentage Replacement of M-Sand in 7 Days Strength

\begin{tabular}{|c|c|c|c|c|}
\hline Mix & $\begin{array}{c}\text { Weight of Cube } \\
(\mathrm{kg})\end{array}$ & $\begin{array}{c}\text { Load } \\
(\mathbf{k N})\end{array}$ & $\begin{array}{c}\text { Compressive } \\
\text { Strength }\left(\mathbf{N} / \mathbf{m m}^{2}\right)\end{array}$ & $\begin{array}{l}\text { Average Compressive } \\
\text { Strength }\left(\mathrm{N} / \mathbf{m m}^{2}\right)\end{array}$ \\
\hline \multirow{3}{*}{$10 \%$} & 8.555 & 662 & 29.42 & \multirow{3}{*}{31.83} \\
\hline & 8.524 & 714 & 31.73 & \\
\hline & 8.477 & 773 & 34.35 & \\
\hline \multirow{3}{*}{$20 \%$} & 8.524 & 745 & 33.11 & \multirow{3}{*}{32.63} \\
\hline & 8.427 & 712 & 31.64 & \\
\hline & 8.379 & 746 & 33.15 & \\
\hline \multirow{3}{*}{$30 \%$} & 8.703 & 789 & 35.06 & \multirow{3}{*}{32.17} \\
\hline & 8.524 & 698 & 31.02 & \\
\hline & 8.641 & 685 & 30.44 & \\
\hline \multirow{3}{*}{$40 \%$} & 8.849 & 693 & 30.08 & \multirow{3}{*}{31.52} \\
\hline & 8.721 & 712 & 31.64 & \\
\hline & 8.746 & 723 & 32.13 & \\
\hline \multirow{3}{*}{$50 \%$} & 8.554 & 727 & 32.31 & \multirow{3}{*}{36.16} \\
\hline & 8.624 & 817 & 36.31 & \\
\hline & 8.703 & 897 & 39.86 & \\
\hline
\end{tabular}

For steel slag aggregate concrete, the fine aggregate was replaced in the percentage level of $10 \%, 20 \%$, $30 \%, 40 \%$ and $50 \%$ by steel slag. The highest strength was obtained at $20 \%$ replacement level when compare with other replacement level. For M-Sand concrete the fine aggregate was replaced in the percentage level of $10 \%, 20 \%, 30 \%, 40 \%$ and $50 \%$ by M-Sand. The highest strength was obtained at $50 \%$ replacement level when compare with other replacement level. For bottom ash concrete, the fine aggregate was replaced in the 
An Experimental Study on the Mechanical and Durability Properties of Concrete: Partial ..

percentage level of $10 \%, 20 \%, 30 \%, 40 \%$ and $50 \%$ by bottom ash. The highest strength was obtained at $40 \%$ replacement level when compare with other replacement level. From the optimum percentage found using compressive strength of the replacement materials, the mechanical and durability properties were arrived.

The maximum compressive strength is up to 28 and 56 days. The compressive strength test results exhibit the mixes are conventional concrete, $20 \%$ steel slag, $40 \%$ bottom ash and $50 \% \mathrm{M}$-sand are $38.54\left(\mathrm{~N} / \mathrm{mm}^{2}\right)$, $38.635\left(\mathrm{~N} / \mathrm{mm}^{2}\right), 40.47\left(\mathrm{~N} / \mathrm{mm}^{2}\right)$ and $43.4\left(\mathrm{~N} / \mathrm{mm}^{2}\right)$. The compressive strength increases the percentage of 0.246 , 5.0 and 12.61 for 28 days similarly the mixes are conventional concrete, $20 \%$ steel slag, $40 \%$ bottom ash and $50 \%$ M-sand $38.58\left(\mathrm{~N} / \mathrm{mm}^{2}\right), 43.72\left(\mathrm{~N} / \mathrm{mm}^{2}\right), 44.93\left(\mathrm{~N} / \mathrm{mm}^{2}\right)$ and $47.67\left(\mathrm{~N} / \mathrm{mm}^{2}\right)$. The compressive strength increases the percentage of $13.32,16.49$ and 23.56 for 56 days respectively to with respect to conventional concrete. The compressive strength is presented Table 6 and results are plotted shown in Figure 1.

Table 6 Compressive Strength Results

\begin{tabular}{|c|c|c|c|c|c|c|}
\hline \multirow[b]{2}{*}{ Materials } & \multicolumn{3}{|c|}{28 Days } & \multicolumn{3}{|c|}{56 Days } \\
\hline & $\begin{array}{l}\text { Weight of } \\
\text { Cube (kg) }\end{array}$ & $\begin{array}{c}\text { Compressive } \\
\text { Strength }\left(\mathbf{N} / \mathbf{m m}^{2}\right)\end{array}$ & $\begin{array}{c}\text { Average } \\
\text { Compressive } \\
\text { Strength } \\
\left(\mathbf{N} / \mathbf{m m}^{2}\right) \\
\end{array}$ & $\begin{array}{l}\text { Weight of } \\
\text { cube }(\mathbf{k g})\end{array}$ & $\begin{array}{c}\text { Compressive } \\
\text { Strength }\left(\mathbf{N} / \mathbf{m m}^{2}\right)\end{array}$ & $\begin{array}{c}\text { Average } \\
\text { Compressive } \\
\text { Strength } \\
\left(\mathbf{N} / \mathbf{m m}^{2}\right) \\
\end{array}$ \\
\hline \multirow{3}{*}{$\begin{array}{l}\text { Conventional } \\
\text { Concrete }\end{array}$} & 8.824 & 38.66 & \multirow{3}{*}{38.54} & 8.762 & 37.42 & \multirow{3}{*}{38.58} \\
\hline & 8.768 & 39.42 & & 8.698 & 39.28 & \\
\hline & 8.634 & 37.56 & & 8.824 & 39.06 & \\
\hline \multirow{3}{*}{ Steel Slag } & 8.653 & 37.688 & \multirow{3}{*}{38.635} & 8.753 & 44.88 & \multirow{3}{*}{43.72} \\
\hline & 8.871 & 38.577 & & 8.894 & 42.84 & \\
\hline & 8.892 & 39.64 & & 8.882 & 43.46 & \\
\hline \multirow[t]{3}{*}{ Bottom Ash } & 8.835 & 41.95 & \multirow{3}{*}{40.47} & 8.876 & 44.35 & \multirow{3}{*}{44.93} \\
\hline & 8.770 & 40.177 & & 8.924 & 44.93 & \\
\hline & 8.635 & 39.288 & & 8.906 & 45.51 & \\
\hline \multirow{3}{*}{ M-Sand } & 8.871 & 41.77 & \multirow{3}{*}{43.4} & 8.922 & 49.51 & \multirow{3}{*}{47.67} \\
\hline & 8.843 & 45.95 & & 8.844 & 46.31 & \\
\hline & 8.852 & 42.48 & & 8.798 & 47.2 & \\
\hline
\end{tabular}

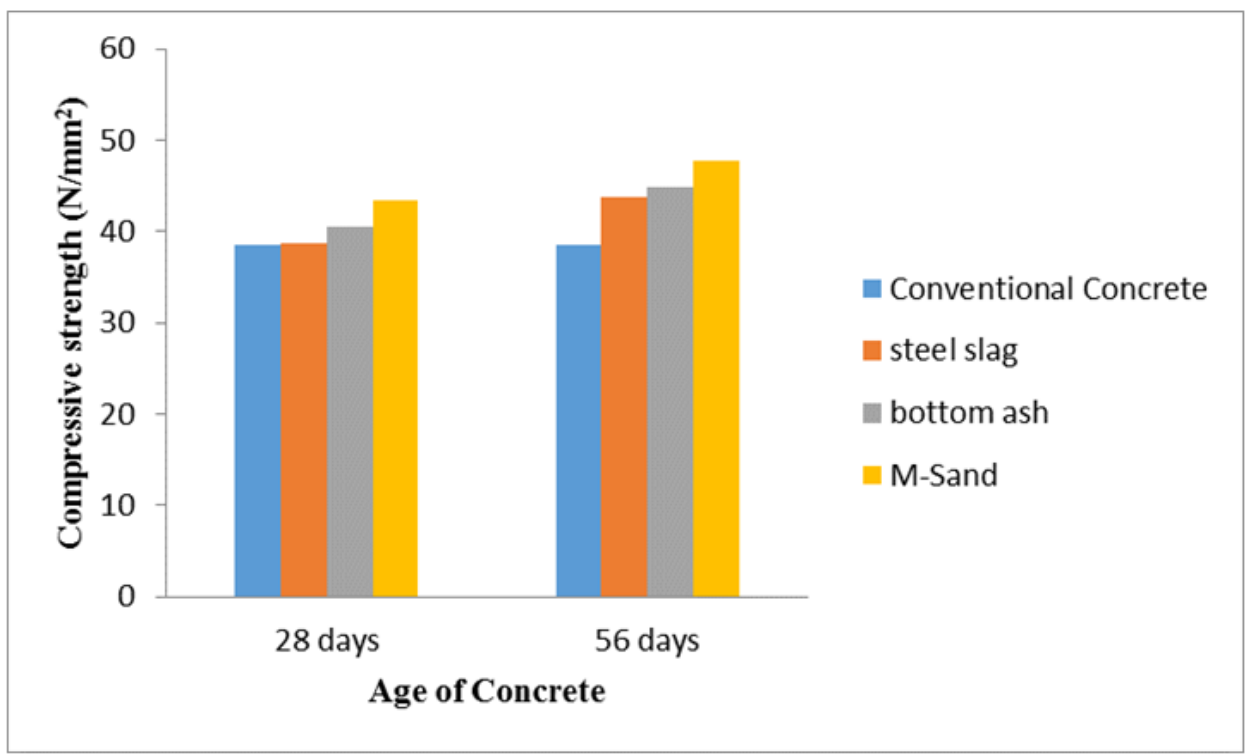

Fig. 1 Compressive Strength of Concrete at 28 Days and 56 Days

The results of flexural strength test were carried out confirming to IS 516-1959 to obtained flexural strength of concrete at the age of 28 days. The maximum flexural strength is up to 28 days. The flexural strength test results exhibits the mixes are conventional concrete, $20 \%$ steel slag, $40 \%$ bottom ash and 50\% M-sand are 4.2, 4.26, 4.46 and 4.866. The Flexural strength increases the percentage of 1.42, 6.19 and 15.8 respectively with respect to conventional concrete. The maximum flexural strength achieved from the mix 50\% M-sand which superior to other concrete mixes. The flexural strength are presented Table 7. 
An Experimental Study on the Mechanical and Durability Properties of Concrete: Partial ..

Table 7 Flexural Strength Results

\begin{tabular}{|c|c|c|c|c|}
\hline Materials & $\begin{array}{l}\text { Weight of } \\
\text { Specimens }\end{array}$ & $\begin{array}{l}\text { Load } \\
\text { (Div) }\end{array}$ & $\begin{array}{c}\text { Flexural Strength } \\
\left(\mathbf{N} / \mathbf{m m}^{2}\right)\end{array}$ & $\begin{array}{c}\text { Avg. Flexural } \\
\text { Strength } \\
\left(\mathrm{N} / \mathbf{m m}^{2}\right)\end{array}$ \\
\hline \multirow[t]{3}{*}{ Conventional Concrete } & 13.276 & 25 & 5 & \multirow{3}{*}{4.20} \\
\hline & 13.105 & 20 & 4 & \\
\hline & 13.045 & 18 & 3.6 & \\
\hline \multirow{3}{*}{$\begin{array}{c}\text { Steel Slag } \\
\text { (20\% Replacement) }\end{array}$} & 12.930 & 22 & 4.4 & \multirow{3}{*}{4.26} \\
\hline & 13.307 & 20 & 4 & \\
\hline & 13.210 & 22 & 4.4 & \\
\hline \multirow{3}{*}{$\begin{array}{c}\text { Bottom Ash } \\
\text { (40\% Replacement) }\end{array}$} & 13.407 & 24 & 4.8 & \multirow{3}{*}{4.46} \\
\hline & 13.090 & 22 & 4.4 & \\
\hline & 12.915 & 21 & 4.2 & \\
\hline \multirow{3}{*}{$\begin{array}{l}\text { Manufacturing Sand } \\
\text { (50\% Replacement) }\end{array}$} & 13.493 & 23 & 4.6 & \multirow{3}{*}{4.86} \\
\hline & 13.627 & 25 & 5 & \\
\hline & 13.458 & 25 & 5 & \\
\hline
\end{tabular}

the properties of materials used, the various test set up and the testing procedure for testing mechanical and durability properties of concrete specimens was discussed in brief. Among all the mechanical properties, on comparing the conventional concrete with replacement materials, steel slag is $20 \%$, bottom ash is $40 \%$ and $\mathrm{m}$ sand is $50 \%$ containing the concrete gives better results.

\section{DURABILITY PROPERTIES}

The permeation properties are low in replacement material as fine aggregate in concrete since, low values were obtained in rapid chloride penetration test. The rapid chloride penetration test the chloride penetration is $20 \%$ steel slag, $40 \%$ bottom ash and $50 \%$ M-sand were decreased $16.48 \%$ respectively with respect to conventional concrete. The chloride penetration is very low in 50\% M-sand was 1867.5 coulombs in the concrete indicating lesser permeability in concrete as per standard. So, the additions of the permeation properties are low in replacement materials as fine aggregate in concrete. The salt resistance testing, conventional concrete and replacement materials show nearby actual compressive strength. Whereas replacement shows less salt resistance when compare to conventional concrete and surface the concrete should be corroded. From the salt resistance test the weight loss in percentage for mixes are conventional concrete, $20 \%$ steel slag, $40 \%$ bottom ash and 50\% M-sand are 0.15, 0.11, 0.11 and 0.09 the loss of percentage weight for 26.66, 26.66 and 40 were found to be mixes are conventional concrete, $20 \%$ steel slag, $40 \%$ bottom ash and $50 \%$ M-sand are 2.62, 2.01, 2.15 and 1.63 the percentage of strength loss. The results indicated that the mix 50\% M-sand subjected to excellent salt resistance. The strength loss was very less $0.09 \%$ in compared other mixes. The sulphate resistance testing, conventional concrete and replacement materials show nearby actual compressive strength. Whereas replacement shows less sulphate resistance when compare to conventional concrete and surface the concrete should be corroded. From the sulphate resistance test the weight loss in percentage for mixes are conventional concrete, $20 \%$ steel slag, $40 \%$ bottom ash and 50\% M-sand are 0.13 , $0.11,0.11$ and 0.10 the loss of percentage weight for $15.38,15.38$ and 23.07 were found to be mixes are conventional concrete, $20 \%$ steel slag, $40 \%$ bottom ash and 50\% M-sand are 1.97, 1.67, 1.43 and 1.33 the percentage of strength loss. The results indicated that the mix 50\% M-sand subjected to excellent sulphate resistance. The strength loss was very less $1.33 \%$ in compared other mixes.

\section{Conclusions}

The fine aggregate which we use for construction is available from natural rivers and streams use of large amount of fine aggregate affects the environment. So, need the alternative materials for natural sand. In the present study, the alternative materials such as steel slag, bottom ash and M-sand by using partial replacement of fine aggregate. Preliminary test such as specific gravity of cement, fine aggregate, coarse aggregate, steel slag, bottom ash and M-sand are carried out and found fit for IS code. From the experimental investigation and regression analysis, the following conclusions were drawn.

- The compressive strength results of M-sand is $12.56 \%$ at 28 days greater than the conventional concrete and also the compressive strength results of steel slag, bottom ash is $0.24 \%, 5 \%$ higher than the conventional concrete.

- The compressive strength results of M-sand at 56 days is $23.56 \%$ greater than the conventional concrete and also the compressive strength results at 56 days of steel slag, bottom ash is $13.32 \%, 16.46 \%$ higher than the conventional concrete.

- The flexural strength was achieved by using $50 \%$ of M-sand concrete obtained as $15.85 \%$ greater than the conventional concrete. The flexural strength of steel slag and bottom ash is $1.43 \%, 6.19 \%$ higher than the conventional concrete. 
- The modulus of elasticity of concrete was achieved by using $50 \%$ of M-sand concrete increased $50 \%$ higher than the conventional concrete, by using steel slag and bottom ash the modulus of elasticity increased $25 \%$ and $33.33 \%$ higher than the conventional concrete.

- From the salt attack test result, the replacement of $50 \% \mathrm{M}$-sand concrete obtained the weight loss of $40 \%$ decreased with respect to conventional concrete and the strength loss also decreased $37.78 \%$ respect to conventional concrete. The weight and strength loss of steel slag, bottom ash is $26.66 \%, 26.66 \%$ and $23.28 \%$, $17.93 \%$ lower than the conventional concrete.

- From the sulphate attack test result, the replacement of 50\% M-sand concrete obtained the weight loss of $23.07 \%$ decreased with respect to conventional concrete and the strength loss also decreased $32.48 \%$ respect to conventional concrete. The weight and strength loss of steel slag, bottom ash is $15.38 \%, 15.38 \%$ and $15.23 \%$, $27.41 \%$ lower than the conventional concrete.

- From RCPT test results that the 50\% of M-sand with fine aggregate chloride penetration was lower when compared to the conventional concrete. Also for steel slag and bottom ash lower than the conventional concrete.

[1]. Arun Kumar. S and Vasudhevan. G (2015), An Experimental Study on Optimum Replacement Level of Fine Aggregate by Steel Slag in Concrete, International Journal on Applications in Civil and Environmental Engineering, Vol.1 (2), pp.17-19.

[2]. Andrade. L.B, Rocha.J.C and Cheriaf.M (2009), Influence of Coal Bottom Ash as Fine Aggregate on Fresh Properties of Concrete, Construction and Building Materials, Vol.23, pp.609-614.

[3]. Carlo Pellegrin Vittorio Gaddo(2009), Mechanical and Durability Characteristic of Concrete Containing EAF Slag as Aggregate, Cement and Concrete Composites, Vol.31, pp.663-671.

[4]. Chetan Khajuria and Rafat Siddique (2014), Use of Iron Slag as Partial Replacement of Sand to Concrete, International Journal of Science, Engineering and Technology Research, Vol.3(6), pp.1877-1880.

[5]. Citlange M.R , Pajgade P.S and Nagarnaik P.B (2014) Experimental study of artificial sand concrete, First International Conference On Emerging Trends in Engineering and Technology, Vol.3, pp.345-347.

[6]. Elavenil. S. and Vijaya. B. (2013), Manufactured Sand, a Solution and an Alternative to River Sand and in Concrete Manufacturing, Journals of Engineering, Computers and Applied Science, Vol.2(2), pp.20-24.

[7]. Iman. M.Nikbin, Saman Rahimi R, Hamed Allahyari and Mohammad Damadi (2016), An Experimental Study on the Mechanical Properties of Concrete Containing Waste Bottom Ash as Natural Aggregate Replacement, Construction and Building Materials, Vol.121, pp.746-759.

[8]. IS 10262:2009, Concrete Mix Proportioning- Guide Lines, Bureau of Indian Standards, New Delhi, India.

[9]. IS 12089:1987 Specifications for Granulated Slag for The Manufacture of Portland Slag Cement, Bureau of Indian Standards, New Delhi, India.

[10]. IS12269:2013 Specification for 53 grade Ordinary Portland Cement (First Revision), Bureau of Indian Standards, New Delhi, India.

[11]. IS 383:1970 Specifications for Coarse and Fine aggregate from Natural Sources for Concrete (Second Revision) Jan 2007, Bureau of Indian Standards, New Delhi, India.

[12]. IS 456:2000 Code of Practice for Plain and Reinforced Concrete, Bureau of Indian Standards, New Delhi, India.

[13]. IS 516;1959 Method of Test for Strength of Concrete, Bureau of Indian Standards, New Delhi, India.

[14]. Liu Chunlin, ZhaKunpeng and Chen Depeng (2011), Possibility of Concrete Prepared With Steel Slag as Fine and Coarse Aggregate,Procedia Engineering, Vol.24, pp.412-416.

[15]. Malkit Singh and Rafat Siddique (2014a), Strength Properties and Micro-Structural Properties of Concrete Containing Coal Bottom Ash as Partial Replacement of Fine Aggregate, Construction and Building Materials, Vol.50, pp.246-256.

[16]. Malkit Singh and Rafat Siddique (2014b), Compressive strength, Drying Shrinkage and Chemical Resistance of Concrete Incorporating Coal Bottom Ash as Partial or Total Replacement of Sand, Construction and Building Materials, Vol.68, pp.39-48.

[17]. MalkitSingh and Rafat Siddique (2013), Effect of Coal Bottom as Partial Replacement of Sand on Properties of Concrete, Resource ,Conservation and Recycling, Vol.72, pp.20-32.

[18]. Naveenth N andSatheeshkumar G (2015), Optimization of Partial Replacement of Natural Sand by Manufacturing Sand in Concrete, International Journal on Application in Science ,Engineering and Technology Vol.1, pp.35-38

[19]. Nimitha Viyayaraghavan and Wayal. A.S(2013), Effect of Manufactured Sand on Compressive Strength and Workability of Concrete, International Journal of Structural and Civil Engineering Research, Vol. 2 (4), pp.228-232.

[20]. Olonade. K.A, Kadir M.B and Aderemi. P.O (2015), Performance of Steel Slag as Fine Aggregate in Structural Concrete, Nigerian Journal of Technology, Vol.34 (3), pp.452-458.

[21]. Priyanka, Jadha. A and Dilip Kulkarni. K (2012), An Experimental Investigation on The Properties of Concrete Containing Manufacturing Sand, International Journal of Advanced Engineering Technology, Vol.3(2), pp.101-104.

[22]. Pruthviraj, L. Kadam (2016), Effect of Partial Replacement of Fine Aggregate by Steel Slag and its Impact on Compressive Strength of Concrete, International Journal of Scientific and Engineering Research, Vol.7 (2), pp.1534-1537

[23]. Soundar Rajan. M (2014), Study on Strength Properties of Concrete by Partially Replacement of Sand by Steel Slag, International Journal on Engineering Technology and Sciences, Vol.1 (6), pp.96-99.

[24]. Subathra Devi. Va nd Gnanavel. B.K (2014), Properties of Concrete Manufactured Using Steel Slag, Procedia Engineering, Vol.97, pp.95-100.

[25]. Wang Qiang, YanPeiyu, Jianwei and Zhang Bo (2013), Influence of Steel Slag on Mechanical Properties and Durability, Construction and Building Materials, Vol.47, pp.1414-1420.

[26]. Yajurved Reddy. M and Swetha D.V (2015), Study on Properties of Concrete with Manufactured Sand as Replacement to Natural Sand, International Journal of Civil Engineering and Technology, Vol.6 (8), pp.29-42. 